\title{
Determination of relationship between basement faults and alteration zones in Bafq-Esfordi region, central Iran
}

\author{
${ }^{1}$ Department of Earth Sciences, Science and Research Branch, Islamic Azad University, Tehran, Iran; *Corresponding author, \\ E-mail:mehranarian@yahoo.com \\ ${ }^{2}$ Department of Mining Engineering, South Tehran Branch, Islamic Azad University, Tehran, Iran \\ ${ }^{3}$ Department of Petroleum Engineering, South Tehran Branch, Islamic Azad University, Tehran, Iran \\ ${ }^{4}$ Department of Geology, Mahallat branch, Islamic Azad University, Markazi Province, Iran
}

(Received: July 11, 2017; Revised accepted: April 25, 2018)

https://doi.org/10.18814/epiiugs/2018/018013

The remote sensing was utilized for mineral exploration specifically to look for the presence of altered minerals. In addition, airborne magnetic data have been used for modelling of basement faults/structures. Furthermore, these data provide a synoptic view, which is helpful in the identification and delineation of various land forms, linear features and structural elements. Moreover, mapping geological lineaments is essential for regional exploration of hydrothermal deposits. The aim of this study is the determination of relationship between faults/structures and hydrothermal alteration zones based on geophysical and remote sensing data in the Esfordi area, central Iran. Basement faults were extracted by magnetic airborne data and alteration zones were detected using remote sensing data. Statistical and geostatistical parameters were determined in this area including correlation between areas of alteration zones and distances to faults, variograms and anisotropic ellipsoid. These reveal that there is a direct correlation between alteration zones and basement faults in the study area.

\section{Introduction}

The multi spectral image is widely used for mineral exploration, specifically to individuate the presence of altered minerals such as alunite, pyrophyllite, kaolinite, sericite, illite and muscovite (Salem et al., 2013). We used it in combination with airborne magnetic data for the determination of basement rocks and faults/structures deeper than $1 \mathrm{~km}$. The airborne geophysical data play a basic role in fault/structural modelling in depth, estimating basement's depth, lithological boundaries, delineation of the deep ore bodies, and modelling of buried fault. In addition, this data provides a synoptic view, which is helpful in identification and delineation of various land forms, linear features and structural elements (Javed and Wani, 2009; Adham et al., 2010). Hence, mapping geologic lineaments is important for identification of alterations (Green et al., 1988; Kujjo, 2010).
Iran is located in the Alpine-Himalayan orogenic and metallogenic belt and hosts base and rare metals deposits. Multi spectral images have been used by researchers for interpretation of the structural features and exploration purposes (Abrams, 2000; Asadi et al., 2007; Azizi et al., 2010; Rajendran et al., 2012). The main aim of this study is the determination of relationship between faults/structures and hydrothermal alteration zones in Esfordi 1:100,000 sheet, central Iran, based on geophysical and remote sensing data.

\section{Geological Setting}

The Esfordi region (Figs. 1 and 2) is located $30 \mathrm{Km}$ east of the city of Bafq, Central Iran. The structural domains occurring in this area include the Anarak-Bafq-Kerman metallogenic belt (Berberian, 1981). The crustal domain referred to as the Central Iranian microcontinent is a composite of three major structural zones, from $\mathrm{E}$ to $\mathrm{W}$ (Alavi, 1991) including Lut, Tabas, and Yazd blocks (Fig. 1b). In addition, there is Posht-e-Badam Block (Alavi, 1991), as a fault-bound, variably deformed and metamorphosed complex of supracrustal rocks that separates the Tabas and Yazd blocks. Alternatively, (Ramezani and Tucker, 2003) defined the Kashmar-Kerman structural zone between the Yazd and Tabas blocks, coinciding with the eastern portion of the Posht-e-Badam Block of (Alavi, 1991) but with slightly different boundaries: the Kuhbanan-Kalmard Fault to the E and the Posht-eBadam Fault to the W (Fig. 1b). The Posht-e-Badam Block is located within an area defined between three major fault systems (Alavi, 1991): Chapedony, Kalmard and Kuhbanan faults (Fig. 1b). A Precambrian crystalline basement and Early Cambrian to Tertiary sedimentary cover are exposed in this block (Forster and Jafarzadeh, 1994). The Precambrian basement consists of medium to high-grade metamorphic rocks, Late Neoproterozoic in age, grouped in the Boneh-Shurow and Poshte-Badam complexes (Ramezani and Tucker, 2003; Verdel et al., 2007). The Posht-e-Badam complex consists of an association of green rocks (e.g., amphibolite, piroxenite), schists, meta-greywackes, marbles, gneisses, amphibolites, pyroxenites, serpentinites, meta-basalts, and conglomerates (Haghipour and Pelissier, 1977). This complex is exposed in the 


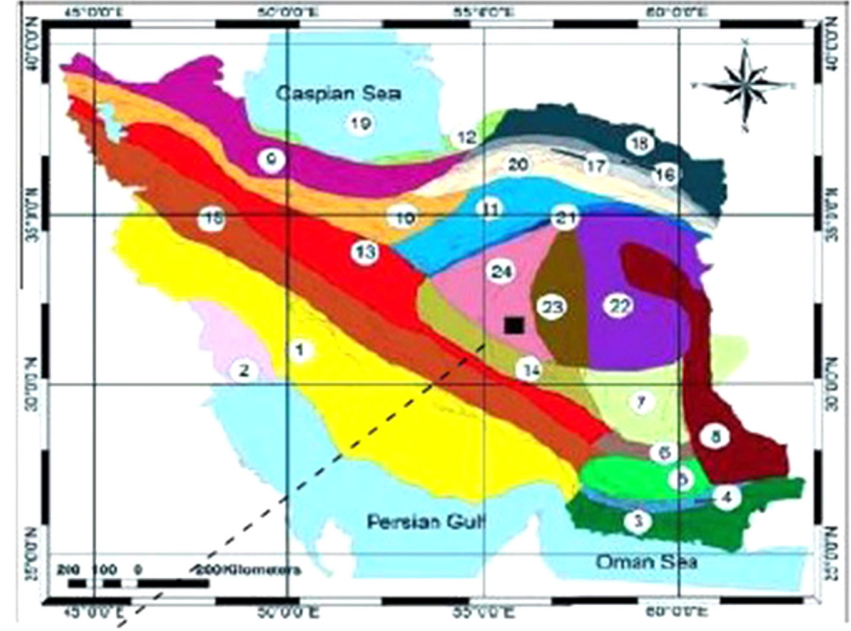

$55^{\circ} \circ \mathrm{O}^{\prime \prime E}$
Numbers in this figure are 1: Zagros-East Tauru hinterland, 2: Persian Gulf-Mesopotamian foreland basin 3: Makran accretionary prism, 4: Bashagardn Mountains, 5: Jazmorian-Mashkel fore arc basin, 6: ShabsavaranSoltan magmatic arc, 7: South Lut-South Helmand back are basin. 8: East Iran Mountain belt, 9: West-Central Alborz and lesser Caucasus hinterland, 10: Great KavirNorthen Urmieh lake foreland basin, 11: South Great Kavirfold and thrust belt, 12: South Caspian-Black sea foreland basin, 13: Urmieh-Dokhtar Magmatic Arc, 14 Naien-Kerman retro are foreland basin, 15: SanandajSirjanoverthrust belts, 16: East Alborz or Binalod hinterland, 17: Torbat-e am-Neysbabour retro arc foreland basin, 18: KopetDagh hinterland, 19: South Caspian remnant basin, 20: Maiamay-Taibad Inverted back arc basin, 21: Khaf-Kavir Plain Magmatic Arc, 22: Lut PlainGonabad back arc besin, 23: Tabas hinterland, 24: YazdKhour Piggy back basin.

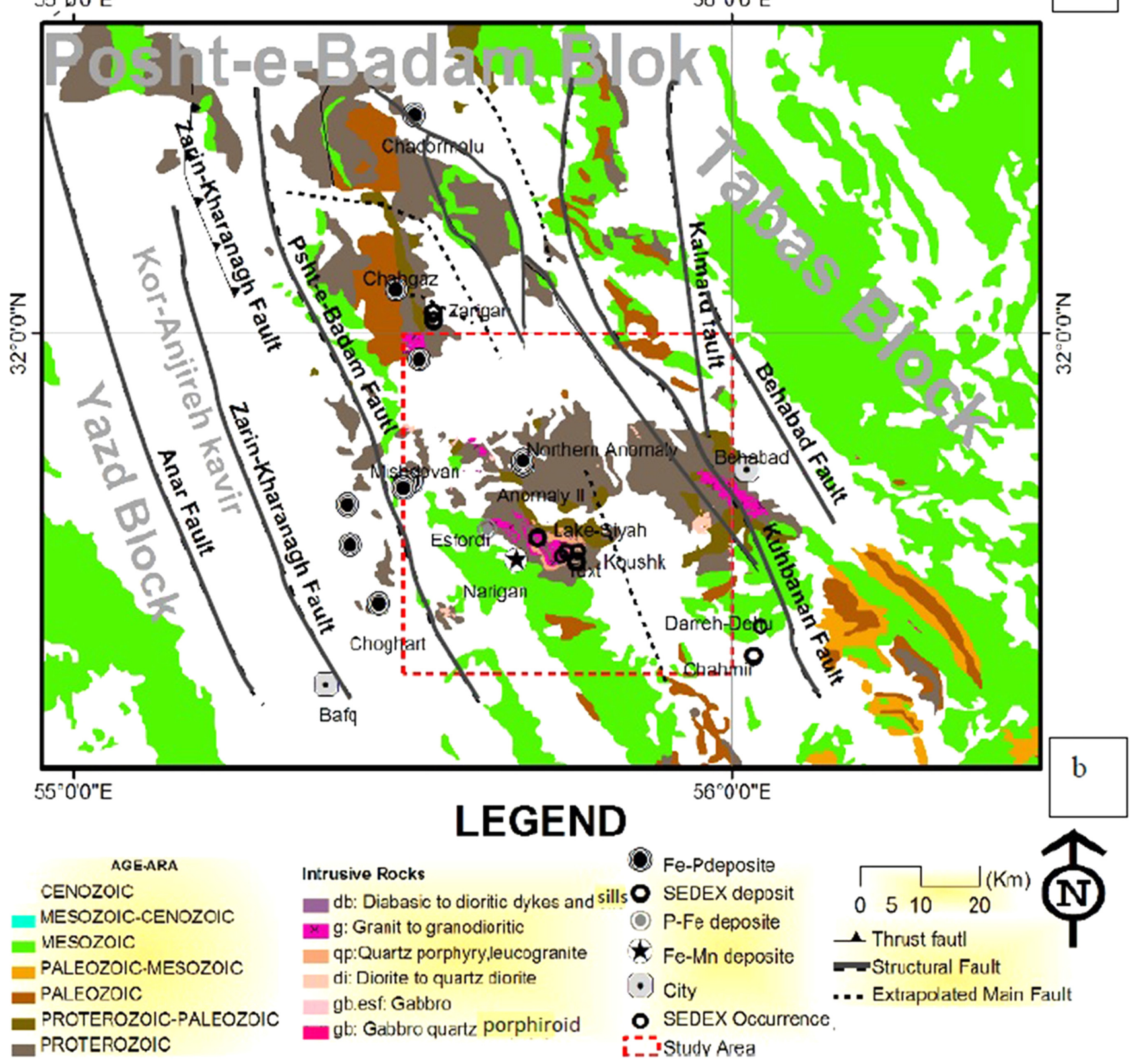

Figure 1. (a) Tectonic scheme of Iran's sedimentary basins (modified from Arian, 2013). (b) Geological map of Posht-e-Badam block, part of Yazd and Tabas blocks with the major faults (Rajabi et al., 2012a), including the Behabad, Kuhbanan, Kalmard, Posht-e-Badam Faults. Main ore deposits are highlighted in the map. The red dashed line rectangle is the extent of the study area. 
west of the Posht-e-Badam fault and is intruded by Triassic granitic plutons (Ramezani and Tucker, 2003). The Boneh-Shurow complex, which is the most widely exposed metamorphic unit, crops out in the east of the Posht-e-Badam Fault (Fig. 1b; Haghipour and Pelissier, 1977). This complex is approximately $2000 \mathrm{~m}$ thick and exhibits a variety of metamorphic rocks, including quartz-feldspathic gneisses, green micaschists and amphibolites (Aghanabati, 2008). The U/Pb dating of this complex indicates a metamorphic age of 602-617 Ma (Ramezani and Tucker, 2003). The Boneh-Shurow complex is covered by a $2000-\mathrm{m}$ thick sequence of greywackes, quartzites and quartzitic schists, marbles, amphibolites, gneiss, slaty-shales, basaltic lavas, sandstones and arkosic arenites, argillites, tuffaceous rocks, as well as limestones of Late Neoproterozoic to Early Cambrian age (Ramezani and Tucker, 2003) that is partly metamorphosed to the greenschist facies. During the Early Cambrian, granitic plutons intruded into the Precambrian sequence of the Tashk formation, and felsic to intermediate volcanic and volcano-sedimentary rocks of the Early Cambrian Volcano-Sedimentary Sequence (ECVSS) were deposited (Daliran et al., 2009). This contact is well exposed in the W and SW of the Narigan area. The ECVSS has also been termed the Cambrian Volcano-Sedimentary Unit (CVSU), Rizu-Desu series and Esfordi Formation, in different parts of the area between the Posht-e-Badam and Kerman areas (Huckriede et al., 1962; Haghipour, 1977; Samani, 1993; Ramezani and Tucker, 2003). The ECVSS consists of an unmetamorphosed sequence of interlayered micro-conglomerates, sandstones, mafic to felsic volcanic rocks, pyritic black siltstones and shales, volcanoclastic beds and tuffaceous shales, dolomites and dolomitic limestones (Haghipour, 1974; Ramezani and Tucker, 2003; Rajabi, 2012) This sequence is host to the most important IOA (Iron Oxide Apatite; Daliran et al., 2009), Fe-Mn and SEDEX Zn-Pb deposits of Iran (Fig. 1b; Rajabi et al., 2012a; Rajabi, 2012, Adib et al., 2017). The upper carbonates of the ECVSS are uncomfortably overlain, in the Zarigan and Chahmir areas, by red conglomerates, sandstones and shales of the Early Cambrian Dahu also called as the Lalun Formation, and by the Middle Cambrian trilobite-bearing Mila Formation (Forster and Jafarzadeh, 1994; Rajabi, 2012). Late Cambrian, Silurian-Permian and Triassic rocks are identified in the region. Rocks of the Jurassic Shemshak formation are exposed in the Chahmir and Koushk areas (Rajabi, 2015); in this place, these rocks are folded and overthrusted by materials of the ECVSS (Rajabi, 2008; Rajabi et al., 2012a), indicating a main post-Cimmerian orogenic event (Aghanabati, 2004). Cretaceous carbonate rocks overlie western parts of the region forming prominent cliffs east and northeast of Bafq. There are mineralizations of different types of iron ores $(>2 \mathrm{Gt})$ which are located in the Bafq district. The largest reserve of iron ore in Bafq region is Chadormalu mine which contains $400 \mathrm{Mt}$ of iron ore (Haghipour, 1977; Samani, 1993; Forster and Jafarzadeh, 1994).

The Bafq region is one of the most important metalogenic zones of Iran which includes the upper Precambrian metamorphic sedimentary rocks and Rift series of Precambrian-Paleozoic (Haghipour, 1977). Central Iran structural zone is a portion of Gondwana land with a Precambrian basement consisting of ignimbrites, ring fracture intrusions, and granites (Fig. 2; Forster and Jafarzadeh, 1994; Daliran et al., 2010). Intrusive rocks host magnetite, apatite-magnetite and Rare Earth Elements (REEs) mineralizations. These mineralized zones are commonly

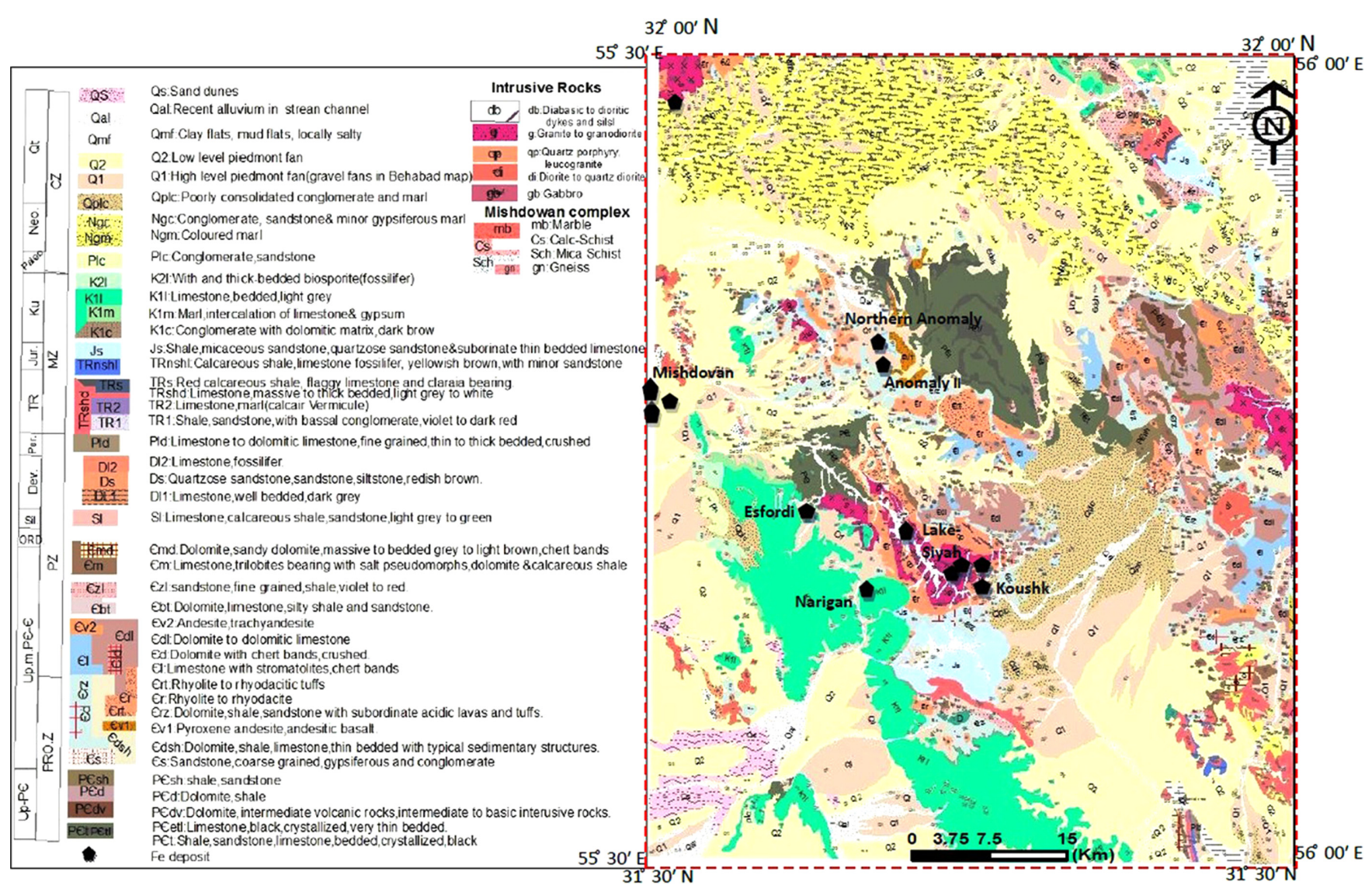

Figure 2. Geological map of study area based on 1:100,000 geological map of Esfordi. This area has shown in Figure 1b by a red dashed rectangle. 
associated with calc-alkaline volcanic rocks and metasomatic alteration of the host rocks. Iron oxide-apatite deposits occur within felsic volcanic tuffs and volcano-sedimentary sequences of the Early Cambrian age (Stosch et al., 2011; Sadeghi et al., 2013). The magnetiteapatite deposits occur in form of several orebodies with large scale replacement and brecciation textures, and a sodic-calcic alteration envelope (Stosch et al., 2011). Previous studies show that the genesis of the iron ores is similar to Kiruna-type deposit (Forster and Jafarzadeh, 1994; Daliran et al., 2010). There are several large and rich iron and iron-apatite deposits and occurrences around the Bafq region, e.g., Chadormalu, Choghart, Seh-Chahoon and Chah-Gaz iron ores and the Esfordi iron-apatite ore deposits (Fig. 1).

The study area occurs in the Bafq mining district, which is part of the narrow N-S trending Pan-African rift zone. Berberian and King (1981) suggested that the development of this rift zone was the result of stretching of the Arabian-Iranian continental crust during an InfraCambrian extensional phase. Forster and Jafarzadeh (1994) suggested that the centers of magmatic activity and maximum crustal thinning coincided with the axis of this assumed rift (Moore and Modabberi,
2003). There are no continuous sedimentary covers because the compressional phases (Cimmerian and later Alpine orogenies) occurred after continental rifting during late Pre-Cambrian to Paleozoic and caused severe erosion.

Also, the related rock units have been widely eroded by later compressional stages in Mesozoic and Cenozoic times, related to the formation of the Yazd-Khour Piggy back basin (Arian, 2013). The dominant trend of faults in this zone is nearly NW-SE and it has been affected by convergent processes during the collision of Cimmerian block with Eurasia since late Triassic from its north margin and the ArabianCimmerian collision since late Cretaceous from its south margin.

Therefore, despite that, from Pre-Cambrian up to present, there were several episodes of magmatism and mineralization, the orebodies and hosted rocks (Infra-Cambrian) have been preserved as the main exposed rocks in the study area. Local faults that crosscut the ore bodies have been already partially investigated at the mine scale by some researchers e.g., Daliran et al. (2009, 2010) Moore and Modabberi (2003) and Forster and Jafarzadeh (1994). With this work we add several information by large scale remote sensing investigation of lineaments and faults.

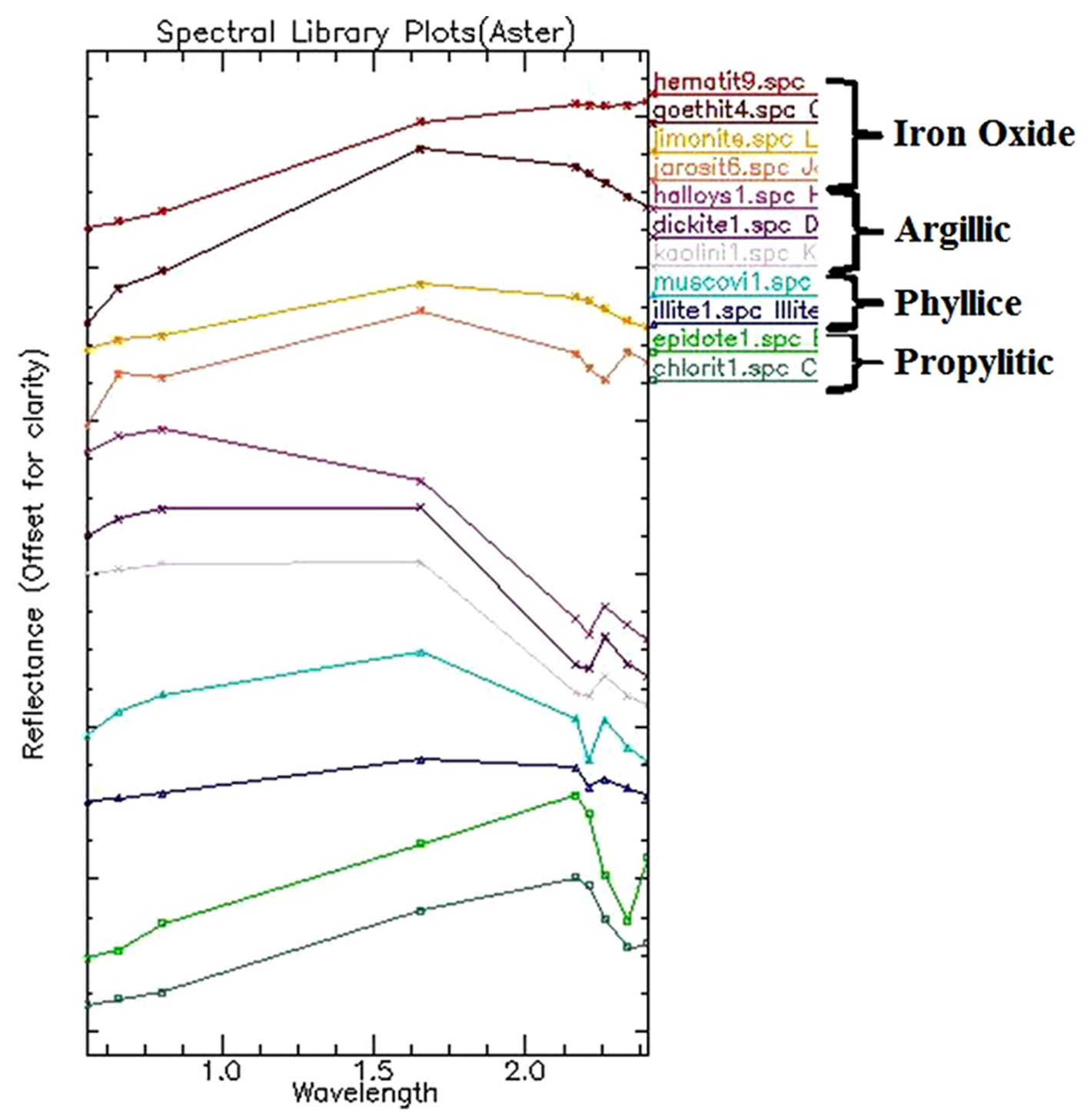

Figure 3. Spectral library plots from USGS library. 


\section{Datasets and Methodology}

The ASTER is an advanced remote sensing sensor which consists of 14 spectral channels varying from the visible to thermal infrared (Watanab and Matsuo, 2011). Different factors are affect signal processing at the sensor such as radiometric calibration, atmospheric and topographical effects. At last, a data set including AST_L1T_ 00306102002070344 20150422202108_63722 in hierarchical data format (HDF) was utilized for this study and radiance correlation consisting of wavelength, dark subtract and log residual was carried out, which is important for multispectral images, and was implemented in this research by ENVI4.8 software.

The magnetometric data with a flight height of $120 \mathrm{~m}$ and a nominal flight line spacing of $500 \mathrm{~m}$ in N45, is provided by Atomic Energy organization. Magnetic data have been prepared after correction of the mea- surements for the daily correction, elimination of the 1975 model of the IGRF (International Geomagnetic Reference Field), and alignment of the magnetic field (Fig. 5).

The Spectral Angle Mapper (SAM) method is a classification technique that allows rapid mapping by calculating the spectral similarity between the image spectrums and to reference reflectance spectra. The SAM measures the spectral similarity by calculating the angle between the two spectra, treating them as vectors in n-dimensional space (Kruse et al., 1993; Pour and Hashim, 2012). The image spectra were compared with USGS Digital Spectral Library (Minerals) (Malekzadeh et al., 2009). Figure 3 shows selected minerals spectral library plots related to iron oxide, argillic, phyllic and propylitic alterations.

The mineral spectral representatives of iron oxide include jarosite, limonite, hematite and goethite; argillic zone include kaolinite, dickite and halloysite; phyllic alteration namely illite and muscovite and also propylitic zone include epidote and chlorite were selected (Fig. 4).

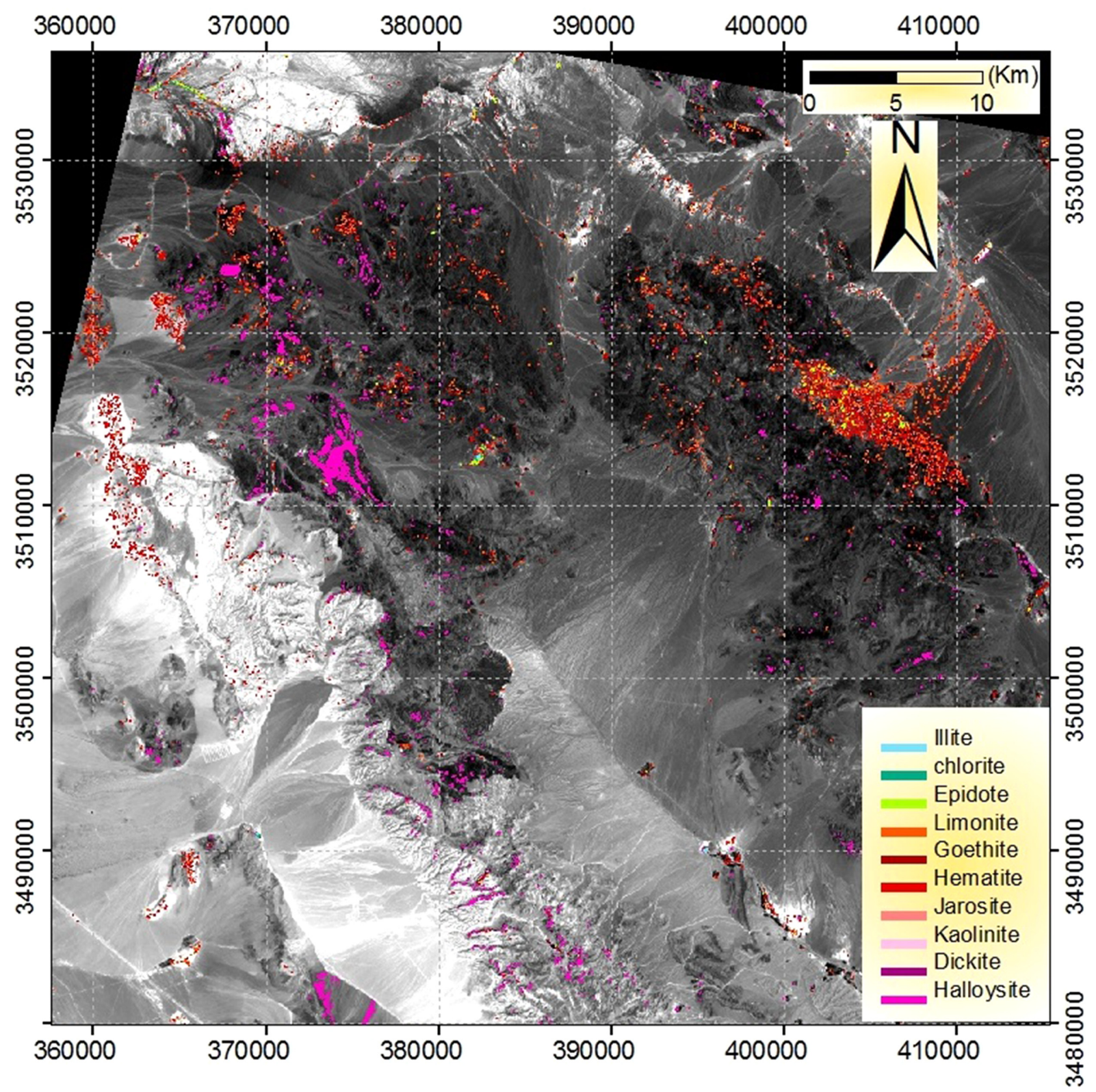

Figure 4. The iron oxide, argillic, phyllic and propylitic alteration zones imaged by SAM method. 


\section{Results}

\section{The First Vertical Derivative (FVD)}

The range of the magnetic field intensity gradient in different directions tends to sharpen the edges of anomalies and enhance shallow for the purpose of enhancing the surface anomaly toward shallow anomaly derivatives (Feumoe et al., 2012). The vertical derivative map is much more responsive to local influences than to broad or regional effects and therefore tends to offer a sharper picture compared to the map of the total field intensity. Thus, the smaller anomalies are more readily apparent in area of strong regional disturbances. The FVD is used to delineate high frequency features more clearly where they are shadowed by large amplitude, low frequency anomalies. The enhancement of magnetic anomalies associated with faults and other structural discontinuities were outlined by the application of the FVD to the residual map in Figure 5 (Dobrin and Savit, 1988). The reprocessed magnetic data set is significantly enhanced in high frequencies and is much better suited to detailed regional shallow mapping and analysis of basement magnetic boundaries.

\section{Lineament Extraction}

To delineate the subsurface structures of the Esfordi region, the air- borne magnetometric data were used and interpreted. This geophysical approach is the FVD method to delineate linear structures. Then, it is incorporated with the shaded relief map model. The Results of this method are used to build a structural model to help in understanding the subsurface structure of the study area. So, the structure of basement faults, many of which being syn-tectonic, (Nabilou et al., 2018) is extracted (Fig. 5a) with the Oasis Montaj software. In Figure 5a, the trend of fault structures is NW-SE and the flower structures diagram (Fig. 5b), shows NW-SE direction. Integration of alteration and lineament (basement magnetic fault) with accordance to geology map of study area is shown in Figure 6. It appears that the direction of mineralized bodies and correlated alteration zones follows the same NWSE trend of faults.

After extracting the iron oxide, argillic, phyllic and propylitic alterations as well as delineating the magnetic map lineament, all of these data have been merged (Fig. 6) in order to understand the structural relationships existing among them.

\section{Spatial Data Analysis}

As a general rule, mineral resource simulation requires suitable statistical tools for better investigation of spatial distribution. Some geostatistical methods are sensitive to the presence of trends in the variability of ore grades (Rossi and Deutsch, 2014). Variogram modelling and estimation is extremely important in structural analysis and spatial
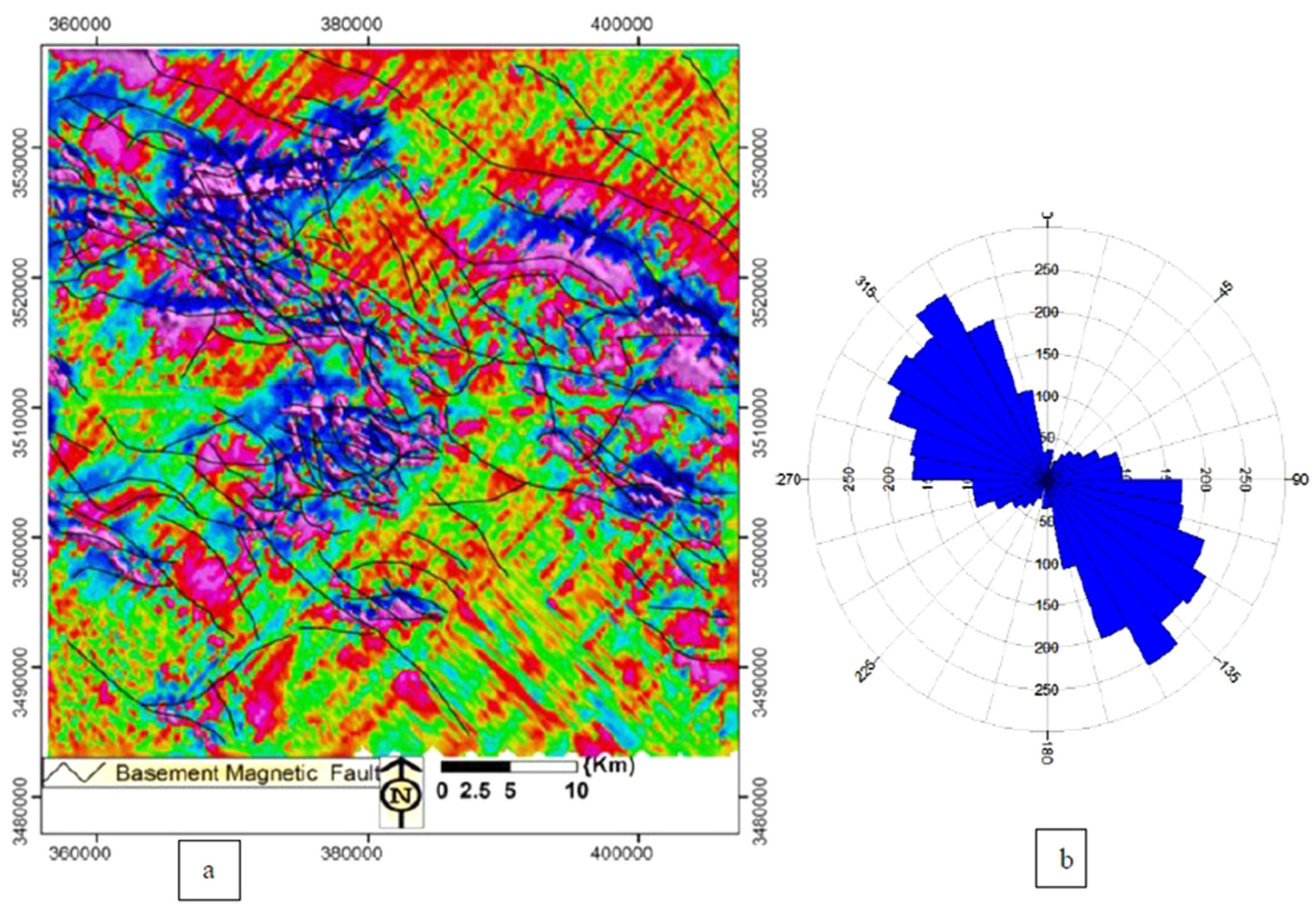

Figure 5. Structural interpretation of magnetic data. (a) Extracted Magnetic basement fault on the magnetic using FVD method. The trend of basement fault is NW-SE. (b) Basement fault Rose diagram that shows direction of fault trend $(N W)$. 


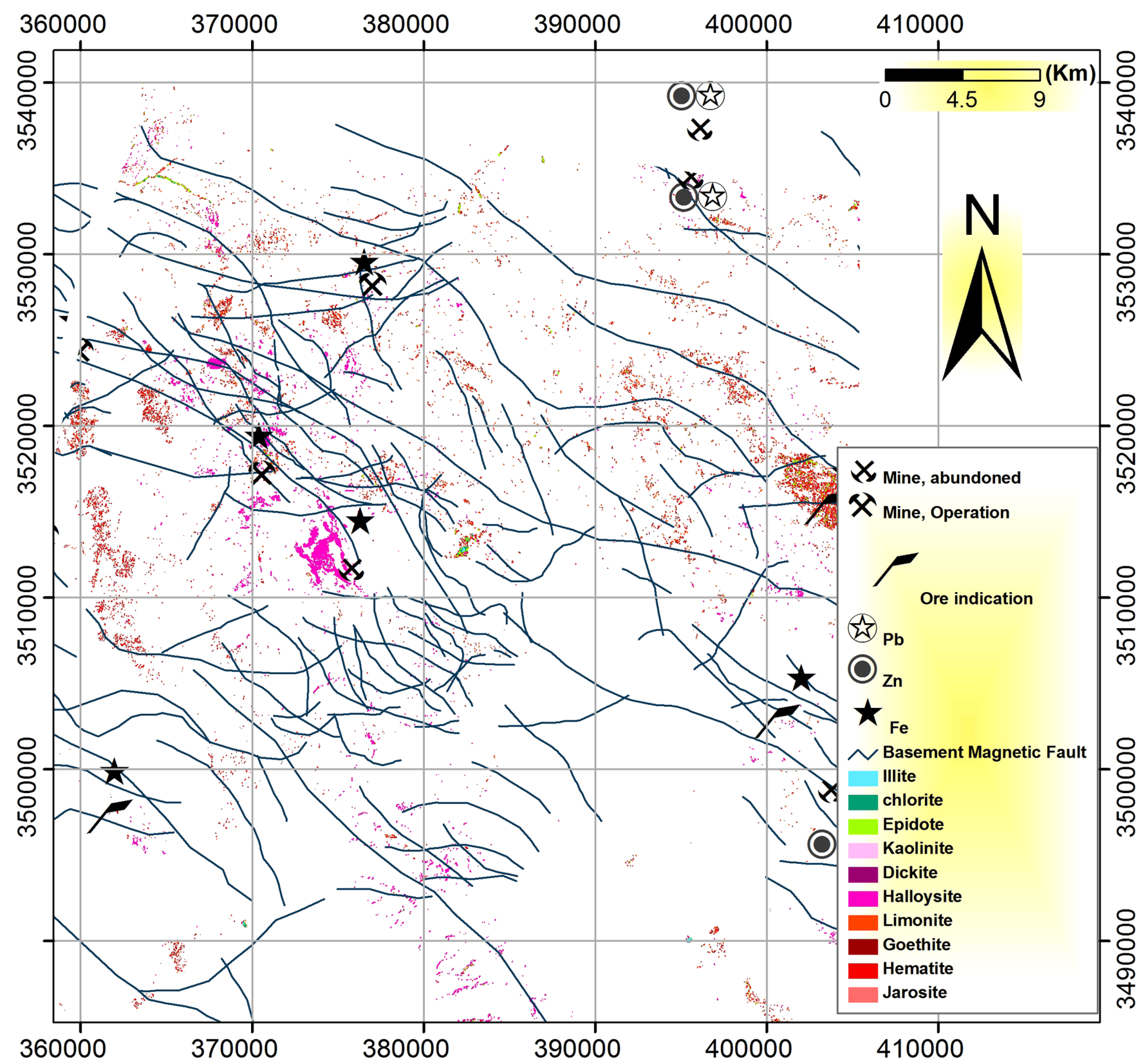

Figure 6. Integration of alteration and magnetic map lineament (basement faults).

interpolation (Burrough and McDonnell, 1998). They are widely used tools for spatial interpolation, which in turn provide the fundamental parameters for geostatistical modelling (VerHoef and Cressie, 1993; Calder and Cressie, 2009; Shahbeik et al., 2014). A variogram map (Deutsch and Journel, 1998), which is a 2-D plot of the sample variogram for all experimentally variable separation vectors, was generated to understand the anisotropy of primary and secondary alterations in the region (Fig. 8). The experimental variogram displays several important features (Webste and Oliver, 2001). The variogram models may consist of simple models, including: Nugget, Exponential, Spherical, Gaussian, Linear, and Power model or the nested sum of one or more simple models (Burrough and McDonnell, 1998; Webster and Oliver, 2001; Pebesma, 2004). For understanding the alteration ellipsoidal anisotropy and its 2D semi-variogram plot, it is necessary to separate all the population distributions of the alterations from each other with drawing separate polygons (Fig. 7). After that, all the alteration areas and the distance from their centers to the basement faults can be measured (Table 2).

In the current study the linear and exponential models were used. Continuity is a measure of geological properties against distance, which can be sensitive to the different directions as in alteration systems. The form of spatial variability in mineralization or alteration systems is called anisotropic behaviour because there is more continuity in one direction than in others. In numerous cases that alteration or mineralization forms to the faults and fractures, the variograms are directional and the deposit is anisotropic, in spatial directions and Followed by the primary (Iron oxide) and secondary (Argillic and proplytic) alteration forms. In anisotropic deposits, the impact Domain $(\gamma)$ is 

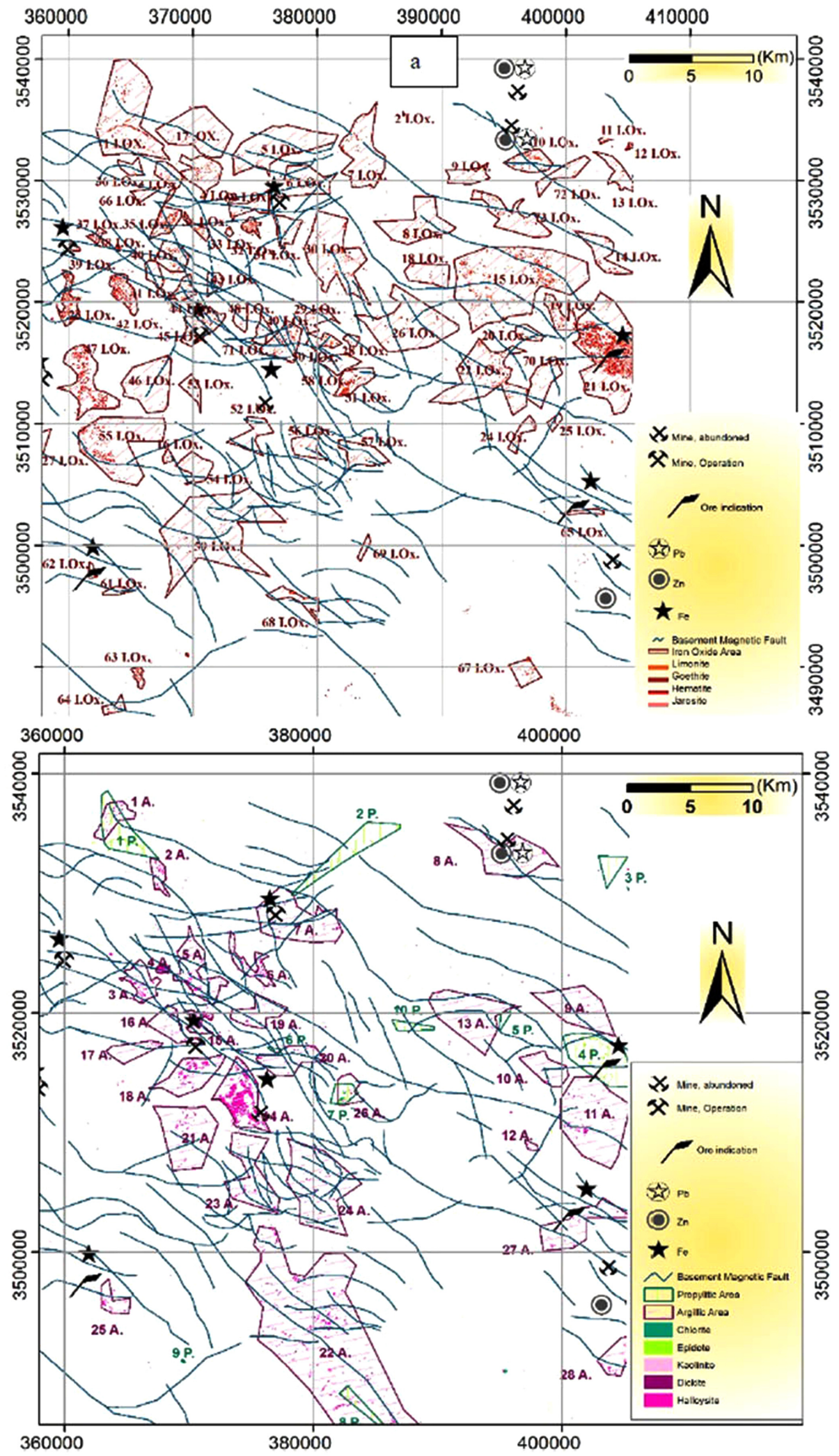

Figure 7. Basement fault have extracted from Magnetic map with the alteration areas consisting of (a) iron oxide (b) argillic and propylitic for determination of the Ellipsoid anisotropy. 


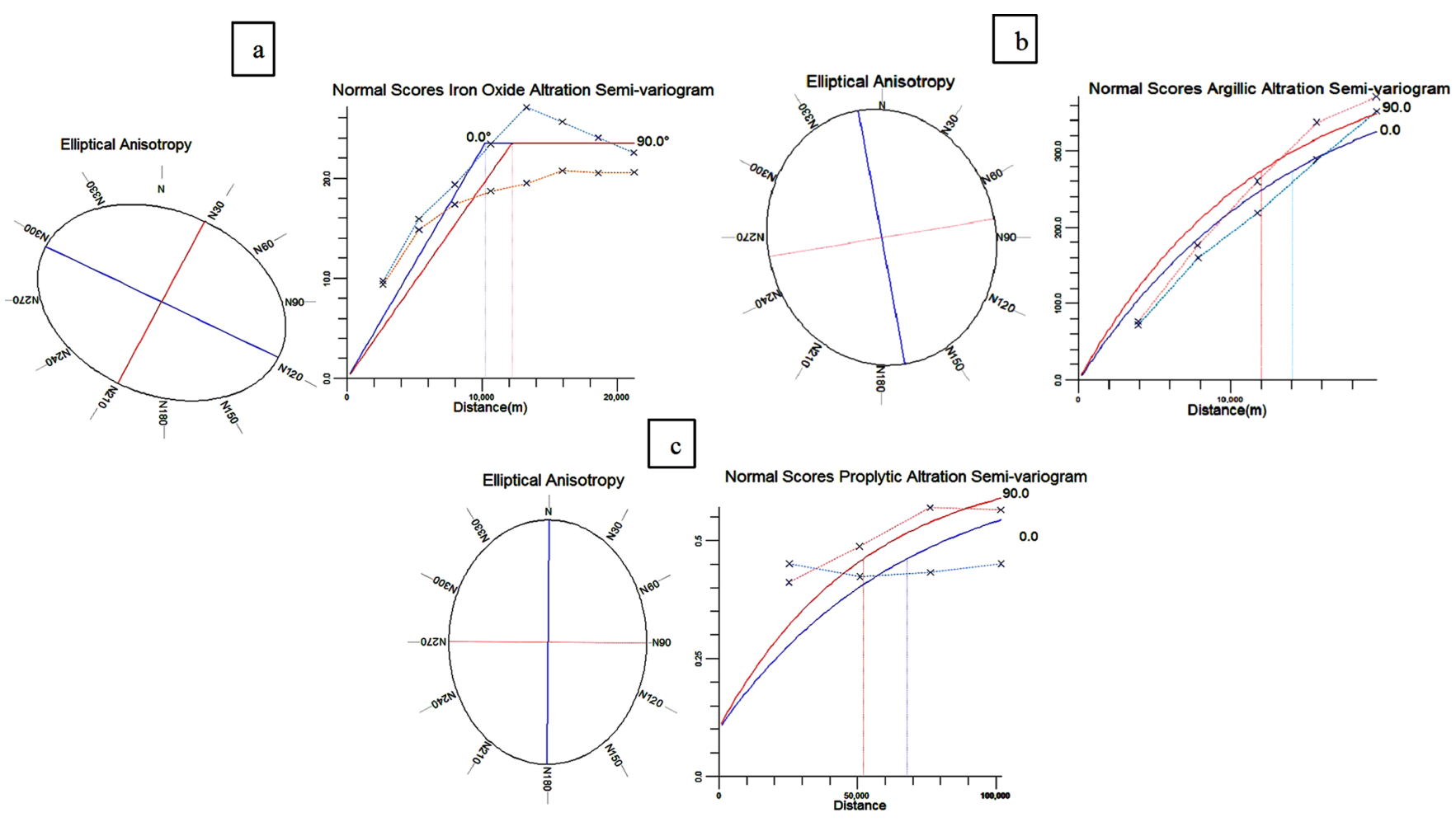

Figure 8. Anisotropic direction for alteration areas based on Ellipsoid Anisotropy and related semi-variogram (major and minor axis). (a) Iron oxide alteration anisotropy. The variogram is without nugget and the direction of the major axis of Ellipsoid anisotropy is NW-SE. (b) Argillic alteration anisotropy. The variogram is without nugget and the direction of the major axis of Ellipsoid anisotropy is $N W-S E$ to $N-S$. (c) Proplytic alteration anisotropy. The variogram is without nugget and the direction of the major axis of Ellipsoid anisotropy is $N$-S.

in various directions. The variograms have different ranges which show anisotropy in this region and main observations are listed below:

- The iron oxide is anisotropic in the plane that the direction of the major axis is roughly $0^{\circ}$ to North West and shows an isotropy in the orthogonal direction to this plane. The rose diagram trend of fault trend (Figs. 5a and b) and the direction of the major axis in ellipsoid anisotropy (Fig. 8a) is correlated with the basement main fault direction.

- The argillic alteration is nearly anisotropic in plan that the direction of the major axis is roughly $0^{\circ}$ to North West near to north and shows an approximate isotropy in the orthogonal direction to this plane. The direction of the major axis in Ellipsoid anisotropy is close to the main fault trend in the basement.

- The propylitic alteration is isotropic in plan that shows anisotropy in the orthogonal direction to this plane. The direction of the major axis in ellipsoid anisotropy is Non-line of the direction of basement main fault (Fig. 8).

In this study, the most important alteration is Iron oxide alteration (Nabilou, 2017) because it is the primary alteration after Fe mineralization. Geostatistical parameters obtained for the Iron oxide alteration are thud discussed here in detail whereas data from the other alterations are reported only in Table 1. Iron oxide model consists of a 0 nugget effect, sill 23.5 and Major Axis Range $13212 \mathrm{~m}$ and minor axis Range $9715 \mathrm{~m}$. The variogram $0^{\circ}$ to the first two directions is shown in Figure 8. It is observed to have a much shorter range of about $2700 \mathrm{~m}$. The ratio of the range of the major axis (Fig. 8a) to the minor axis (Fig. 6a and Table 1) is 1.36. Therefore, in the second stage, it is crucial to detect possible trends of expanse of alteration areas that are determined with drawing polygons (Figs. 7a and b) after the determination of the alterations using the same method. However, the geostatistical results about the iron oxide and argillic alteration indicate that they are anisotropic and with the same expanse to NW-SE direction in Ellipsoid anisotropy, On the contrary, the propylitic alteration shows its expanse in the N-S direction, which does not coincide with the trend of basement faults.

The correlation diagram is commonly used with forecasting purposes in mineral resources exploration and extraction. The spatial arrangement of alteration areas (iron oxide, Argillic and propylitic in Fig. 9) with respect to basement faults can be used to forecast the occurrence of ore bodies by using the correlation diagram and the associated linear equations. The linear regression is a kind of regression that is used in this study. Based on the correlation diagrams, the iron oxide and propylitic alterations' alteration areas increased with respect to decrease in the distances to the nearest basement fault (Figs. 9a and c). The argillic areas decreased when the distances to the nearest basement fault increased (Fig. 9b).

\section{Discussion}

To evaluate the ASTER satellite data, specific alteration zones and lineaments, field-checks have been performed. In almost all cases, our fieldwork indicated the real alteration and detected of area of linea- 
Table 1. The table shows the measurement results of the alteration area and the distance of the center of the alteration area to the nearest basement fault

\begin{tabular}{|c|c|c|c|c|c|c|c|c|c|c|c|c|c|c|}
\hline \multicolumn{10}{|c|}{ Iron Oxide } & \multicolumn{5}{|c|}{ Argillic } \\
\hline No. & $X$ & $\mathrm{Y}$ & \begin{tabular}{|c|} 
Distance \\
$(\mathrm{Km})$
\end{tabular} & $\begin{array}{l}\text { Area } \\
\left(\mathrm{km}^{2}\right)\end{array}$ & No. & $X$ & $\mathrm{Y}$ & \begin{tabular}{|c|} 
Distance \\
$(\mathrm{Km})$
\end{tabular} & $\begin{array}{l}\text { Area } \\
\left(\mathrm{km}^{2}\right)\end{array}$ & No. & $X$ & Y & \begin{tabular}{|c|} 
Distance \\
$(\mathrm{Km})$
\end{tabular} & $\begin{array}{l}\text { Area } \\
\left(\mathrm{km}^{2}\right)\end{array}$ \\
\hline 1I.OX. & 365221 & 3535799 & 0.36 & 29.13 & 38I.OX. & 363950 & 3524518 & 0.212 & 0.13 & $1 \mathrm{~A}$. & 364053 & 3536058 & 0.156 & 5 \\
\hline 2I.OX. & 386941 & 3535504 & 3.957 & 0.02 & 39I.OX. & 360349 & 3524512 & 0.494 & 0.44 & $2 \mathrm{~A}$ & 367689 & 3531337 & 0.191 & 2.5 \\
\hline 3 I.OX. & 368047 & 3530462 & 0.216 & 3 & 40I.OX. & 367777 & 3526504 & 0.052 & 3.75 & $3 \mathrm{~A}$. & 366080 & 3522650 & 0.099 & 5.44 \\
\hline 4I.OX. & 370626 & 3530393 & 1.555 & 6.5 & 41I.OX. & 366880 & 3522271 & 0.122 & 2.2 & 4A. & 367925 & 3523670 & 0.065 & 0.54 \\
\hline 5I.OX. & 377064 & 3533048 & 0.2 & 19.24 & 42I.OX. & 364388 & 3520569 & 1.31 & 4.15 & $5 \mathrm{~A}$. & 370972 & 3523938 & 0.023 & 10 \\
\hline 6I.OX. & 378780 & 3529946 & 0.055 & 9.52 & 43I.OX. & 371895 & 3521334 & 0.095 & 1.78 & 6A. & 375049 & 3524531 & 0.393 & 4.32 \\
\hline 7I.OX. & 363608 & 3532904 & 0.223 & 14.06 & 44I.OX. & 369057 & 3521122 & 0.048 & 2.51 & 7A. & 378862 & 3528122 & 0.002 & 20.13 \\
\hline 8I.OX. & 387832 & 3526681 & 0.65 & 11.69 & 45I.OX. & 370822 & 3518003 & 0.18 & 5.28 & $8 \mathrm{~A}$. & 395150 & 3533552 & 0.185 & 16.18 \\
\hline 9I.OX. & 392117 & 3530556 & 2.39 & 3.43 & 46I.OX. & 366282 & 3513264 & 0.42 & 12.66 & 9A. & 400945 & 3520176 & 0.041 & 14.26 \\
\hline 10I.OX. & 396977 & 3531607 & 0.15 & 4.82 & 47I.OX. & 361587 & 3513378 & 3.63 & 11.88 & $10 \mathrm{~A}$. & 398581 & 3515329 & 0.029 & 6.5 \\
\hline 11I.OX. & 403472 & 3533331 & 2.289 & 0.5 & 48I.OX. & 373808 & 3518503 & 0.18 & 1.73 & $11 \mathrm{~A}$. & 402717 & 3510857 & 0.58 & 30.19 \\
\hline 12I.OX. & 405115 & 3532863 & 1.702 & 0.2 & 49I.OX. & 377084 & 3516750 & 0.29 & 6.35 & $12 \mathrm{~A}$. & 397622 & 3508969 & 0.654 & 0.57 \\
\hline 13I.OX. & 403842 & 3530690 & 3.338 & 3.25 & 50I.OX. & 380569 & 3516723 & 0.061 & 2.23 & $13 \mathrm{~A}$. & 393031 & 3519202 & 0.935 & 19.02 \\
\hline 14I.OX. & 403157 & 3524049 & 0.419 & 5.58 & 51I.OX. & 377407 & 3532469 & 0.65 & 16.63 & $14 \mathrm{~A}$. & 374222 & 3513207 & 1.385 & 13.78 \\
\hline 15I.OX. & 396382 & 3521024 & 0.53 & 48.15 & 52I.OX. & 374576 & 3508986 & 0.21 & 4.29 & $15 \mathrm{~A}$. & 370765 & 3519277 & 0.029 & 2.58 \\
\hline 16I.OX. & 368068 & 3507355 & 0.17 & 0.66 & 53I.OX. & 369722 & 3512478 & 2.7 & 2.26 & $16 \mathrm{~A}$. & 368890 & 3519004 & 0.335 & 5.56 \\
\hline 17I.OX. & 370055 & 3533974 & 0.24 & 15.4 & 54I.OX. & 370152 & 3506353 & 0.71 & 4.29 & 17A. & 365622 & 3516686 & 0.599 & 4.61 \\
\hline 18I.OX. & 388869 & 3522152 & 0.98 & 5.67 & 55I.OX. & 364258 & 3507711 & 1.07 & 23.04 & $18 \mathrm{~A}$. & 369901 & 3514767 & 0.314 & 9.86 \\
\hline 19I.OX. & 399565 & 3519156 & 1.246 & 3.85 & 56I.OX. & 379357 & 3508162 & 0.251 & 3.77 & 19A. & 375742 & 3520059 & 0.015 & 6.64 \\
\hline 20I.OX. & 397077 & 3517464 & 0.141 & 2.18 & 57I.OX. & 383762 & 3507453 & 0.303 & 5.1 & $20 \mathrm{~A}$. & 378262 & 3515996 & 0.002 & 8.2 \\
\hline 21I.OX. & 402972 & 3515811 & 0.3 & 32.03 & 58I.OX. & 381877 & 3514883 & 0.37 & 3.3 & $21 \mathrm{~A}$. & 369748 & 3509530 & 0.052 & 19.22 \\
\hline 22I.OX. & 392973 & 3513873 & 0.63 & 18.86 & 59I.OX. & 372253 & 3500206 & 0.1 & 42.75 & $22 \mathrm{~A}$. & 382413 & 3490483 & 0.391 & 146 \\
\hline 23I.OX. & 359977 & 3520325 & 0.612 & 3.77 & 60I.OX. & 374446 & 3527897 & 0.12 & 3.44 & $23 \mathrm{~A}$. & 375072 & 3506682 & 0.098 & 15.22 \\
\hline 24I.OX. & 396476 & 3509125 & 1.054 & 2.28 & 61I.OX. & 363981 & 3496249 & 0.066 & 1.04 & $24 \mathrm{~A}$. & 380919 & 3505444 & 0.432 & 27.53 \\
\hline 25I.OX. & 399105 & 3510100 & 0.131 & 0.83 & 62I.OX. & 361927 & 3497958 & 0.99 & 0.56 & $25 \mathrm{~A}$. & 364091 & 3496321 & 0.118 & 3.53 \\
\hline 261.OX. & 387228 & 3518575 & 0.71 & 21.58 & 63I.OX. & 365579 & 3489096 & 1.906 & 0.97 & $26 \mathrm{~A}$. & 383041 & 3513556 & 0.804 & 3.72 \\
\hline 27I.OX. & 357422 & 3508123 & 0.26 & 3.37 & 64I.OX. & 363635 & 3486888 & 0.046 & 1.32 & $27 \mathrm{~A}$. & 401760 & 3502345 & 0.407 & 12.44 \\
\hline 28I.OX. & 382705 & 3516849 & 0.222 & 0.84 & 65I.OX. & 401292 & 3502747 & 0.331 & 0.93 & $28 \mathrm{~A}$. & 404078 & 3491326 & 0.59 & 4.98 \\
\hline 29I.OX. & 380454 & 3518468 & 0.32 & 2.64 & 66I.OX. & 366217 & 3528765 & 0.58 & 1.3 & & & Propylitic & & \\
\hline 30I.OX. & 381591 & 3523651 & 0.19 & 20.58 & 67I.OX. & 396739 & 3489521 & 5.28 & 3.56 & No. & $X$ & Y & $\begin{array}{c}\text { Distance } \\
(\mathrm{Km})\end{array}$ & $\begin{array}{l}\text { Area } \\
\left(\mathrm{km}^{2}\right)\end{array}$ \\
\hline 31I.OX. & 377643 & 3525767 & 0.095 & 3.64 & 68I.OX. & 378048 & 3495111 & 0.306 & 3.3 & $1 \mathrm{P}$. & 365274 & 3535728 & 0.283 & 10.59 \\
\hline 32I.OX. & 374703 & 3526124 & 0.654 & 1.31 & 69I.OX. & 383778 & 3499824 & 0.152 & 0.8 & $2 \mathrm{P}$. & 382647 & 3532895 & 0.821 & 10.78 \\
\hline 33I.OX. & 372932 & 3525767 & 0.516 & 0.29 & 70I.OX. & 398237 & 3513272 & 1.22 & 5.93 & $3 \mathrm{P}$. & 404084 & 3531773 & 2.587 & 3.16 \\
\hline 34I.OX. & 370297 & 3526201 & 0.175 & 1.29 & 71I.OX. & 375633 & 3517770 & 0.21 & 1.93 & $4 \mathrm{P}$. & 403047 & 3516089 & 0.565 & 16.129 \\
\hline 35I.OX. & 367774 & 3526509 & 0.195 & 3.71 & 72I.OX. & 399762 & 3530357 & 0.69 & 4.15 & $5 \mathrm{P}$. & 39563 & 3519355 & 0.907 & 0.69 \\
\hline 36I.OX. & 364952 & 3531149 & 0.042 & 1.72 & 73I.OX. & 395657 & 3527255 & 0.26 & 9.36 & $6 \mathrm{P}$. & 376955 & 3516835 & 0.078 & 0.32 \\
\hline 37I.OX. & 362218 & 3525449 & 0.105 & 0.83 & - & - & - & - & - & $7 \mathrm{P}$ & 382546 & 3513243 & 1.243 & 2.17 \\
\hline- & - & - & - & - & - & - & - & - & - & 8 P. & 384675 & 3486491 & 1.384 & 3.35 \\
\hline- & - & - & - & - & - & - & - & - & - & $9 \mathrm{P}$. & 369559 & 3490956 & 1.13 & 0.05 \\
\hline- & - & - & - & - & - & - & - & - & - & $10 \mathrm{P}$. & 388059 & 3518942 & 0.161 & 1.9 \\
\hline
\end{tabular}


Table 2. The table shows the measurement results of semi-variogranm and Ellipsoid anisotropy

\begin{tabular}{|c|c|c|c|}
\hline \multicolumn{3}{|c|}{ Anisotropy area Geostatistic } \\
\hline \multicolumn{2}{|c|}{ Alteration } \\
\hline Ellipsoid anisotropy components & Iron oxide & Argillic & Propylitic \\
\hline Diagram type & Linear & Exponential & 0.54 \\
\hline Correlation & 0.93 & 0.99 & 0.77 \\
\hline Anisotropy ratio & 0.74 & 0.84 & 0.1 \\
\hline Nugget & 0 & 0 & 0.57 \\
\hline Relative sill & 23.5 & 432.5 & 0.5 \\
\hline Major axis direction & 116.9 & 170 & 90.5 \\
\hline Minor axis direction & 26.9 & 80 & 67947 \\
\hline Major axis range (m) & 13212 & 14142 & 52401 \\
\hline Minor axis range (m) & 9715 & 11942 & 0.45 \\
\hline Sill & 23.5 & 1.184 & 1.3 \\
\hline
\end{tabular}
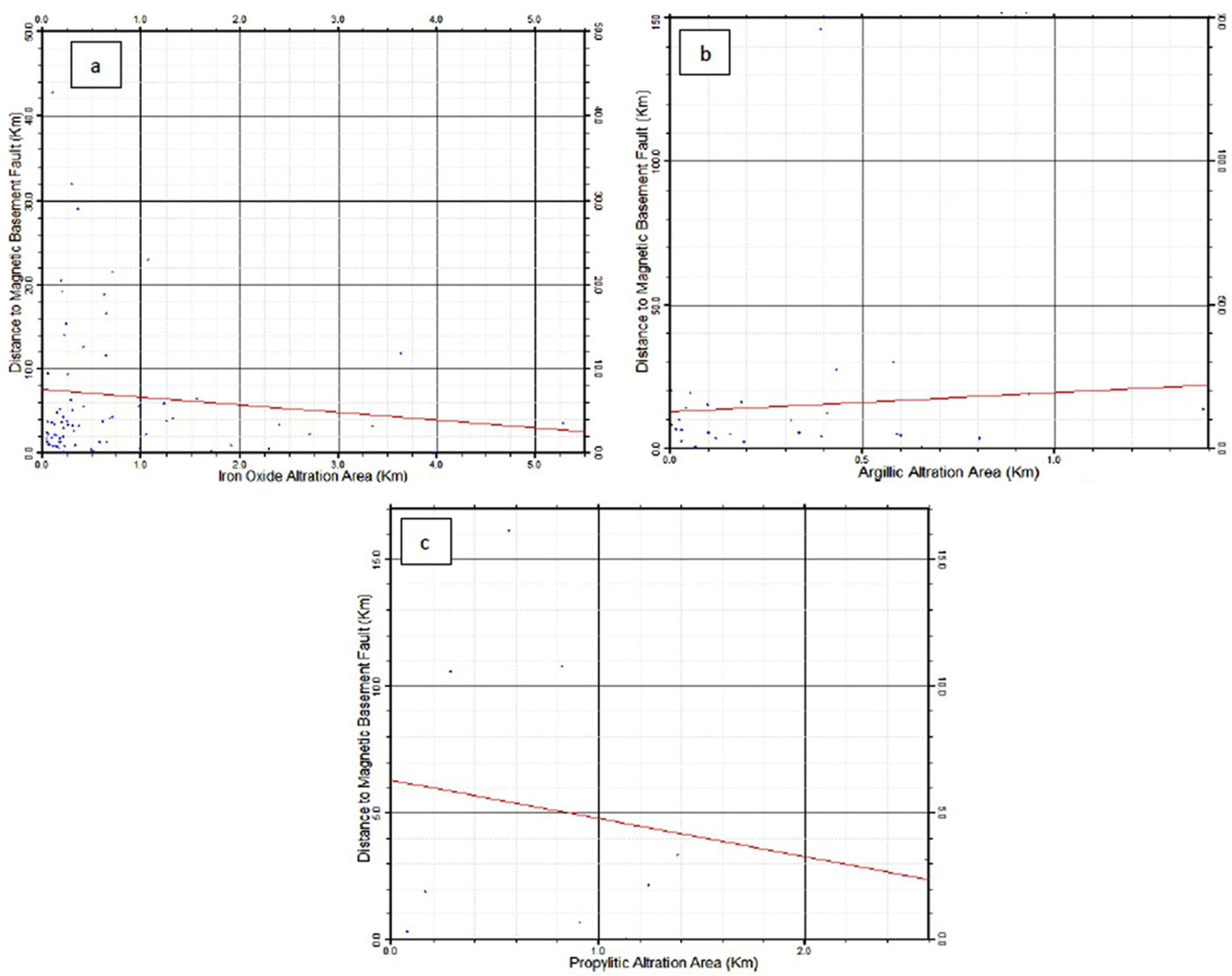

Figure 9. Correlation and linear regression diagram between iron oxide (a), argillic (b) and propylitic alteration (c) areas with distance from basement faults. 

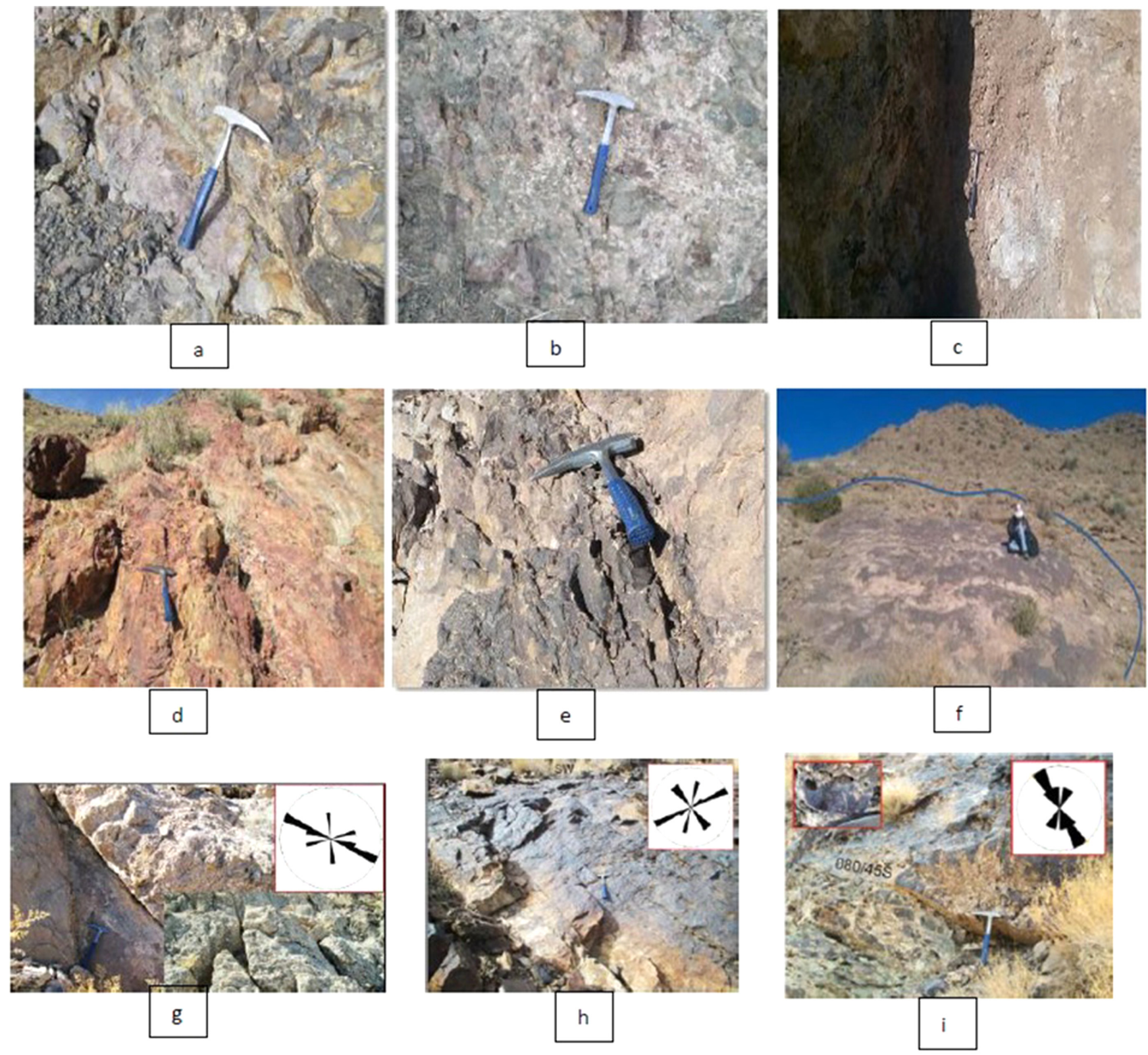

Figure 10. Field photographs of the study area. (Final report of Gazestan, 2015) (a) View of dickite unit with the andesite part (Hematite with iron oxide). (b) Chlorite alteration in metasomatic rocks. (c) View of argillic alteration in metasomatism rhyolite rocks (include of illite, montmorillonite, dickite). (d) View of the hematite colonization in dacitic-rhyolitic unit. (e) View of quartz dioritic unit, secondary minerals contains calcite, muscovite, biotite, chlorite and opaque minerals. (f) View of pink sub volcanic dacitic unit in Dolostone unit. (g-i) Lineaments (master joints) with rose diagrams in different directions.

ment by the interpreted remote sensing imagery. The field photographs of the hydrothermally altered rocks are illustrated in Figure 10. Microscopic photographs and XRD analysis of the study areas are shown in Figure 11 and Table 3, respectively.

\section{Conclusions}

The use of remote sensing data in the early stages of mineral exploration proved highly successful in recognition of the hydrothermal alterations. Moreover, the airborne magnetic map is used for the iden- tification of lineaments possibly corresponding to basement faults which are poorly visible in the field. The form of iron oxide primary alteration Follow up main faults (basement fault) trends, According to alignment of the direction of the major axis of Ellipsoid anisotropy with the basement fault directions. Therefore, the highest levels of propagation of alterations are in the direction of the Ellipsoid axis trend. Also, there are two ideal diagrams of primary iron oxide and secondary proplytic alterations for gaining the best result from correlation between the alteration area strike and the basement fault strike trend (NW-SE).

Argillic and propylitic alterations correspond to the observed base- 

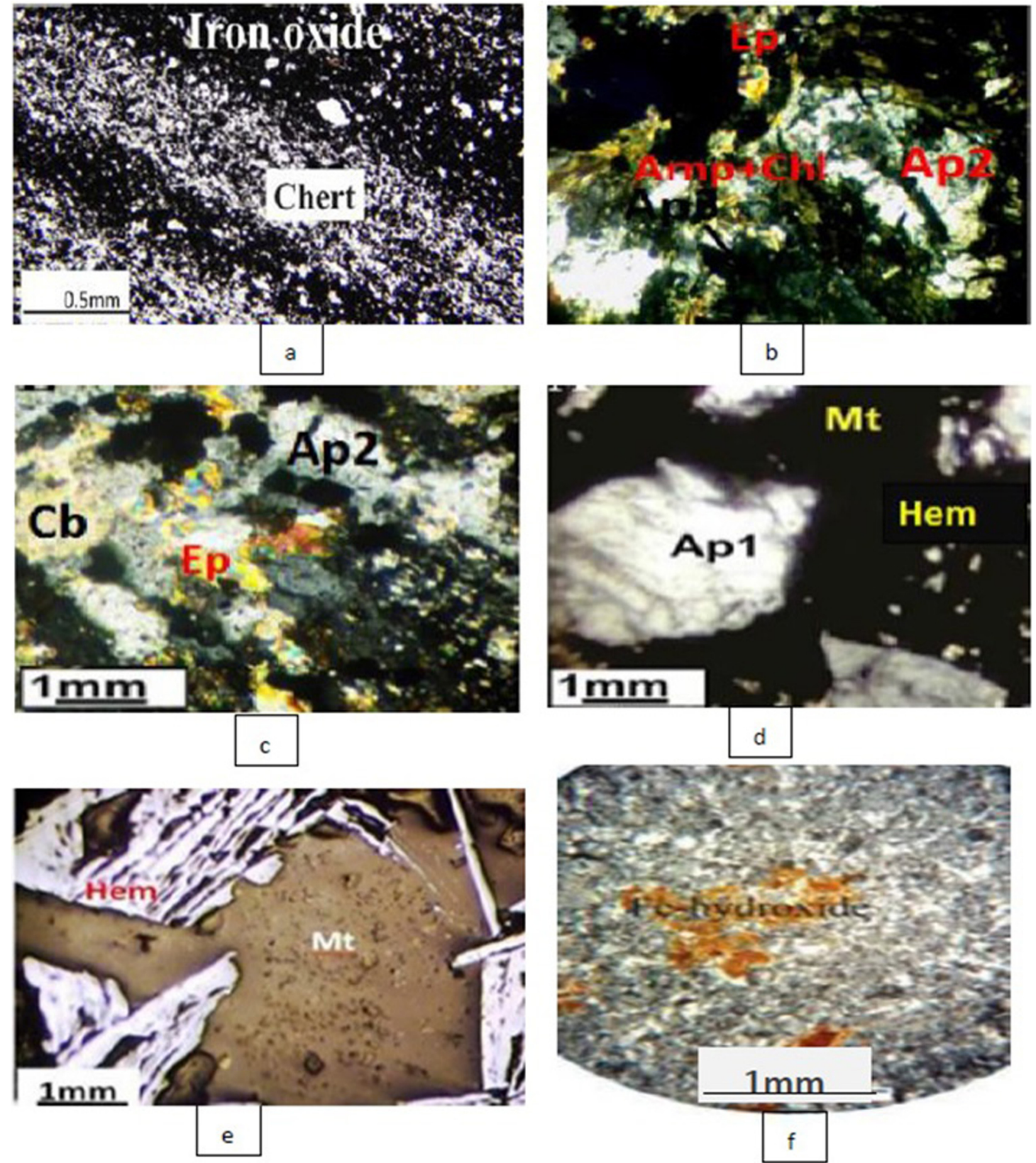

Figure 11. Microscopic photographs of samples from the study areas in transmitted (a, b, $c$, d, and f) and reflected light (e). (a) Banded iron oxide and chert (crossed nicols, after Mohseni and Aftabi, 2015). (b) Apatite 2 mineralization in relation to hydro minerals amphibole, chlorite and epidote (4×-crossed nicols) (Rajabzadeh et al., 2014). (c) late mineralization of calcite and quartz (10×-crossed nicols). Mt: magnetite, Hem: hematite, Ap 1: apatite 1, Ap 2: apatite 2, Ap 3: apatite 3, Amp: amphibole, Ep: epidote, Chl: chlorite, Qz: carbonate (Rajabzadeh et al., 2014). (d) Apatite 1 mineralization in relation to iron oxide-rich cores (10×-crossed nicols) (Rajabzadeh et al., 2014). (e) Needle-shaped actinolite adjacent to phosphate mineralization (10×-crossed nicols). Mt: magnetite, Hem: hematite, Act: actinolite (Rajabzadeh et al., 2014). (f) Quartz small crystrals and alkali-feldspar with secondary hydroxide in feldspar matrix in the Kuh-e-Siah rhyolites (crossed nicols) (Mohamadi et al., 2016). 
Table 3. The table shows the results of XRD analysis of 4 deposit contains of Esfordi (Rajabzadeh et al., 2014), Mishdovan (Namiranian and Kalantar, 2014), Choghart (Barani et al., 2011) and Gazestan deposits (Final report of Gazestan, 2015)

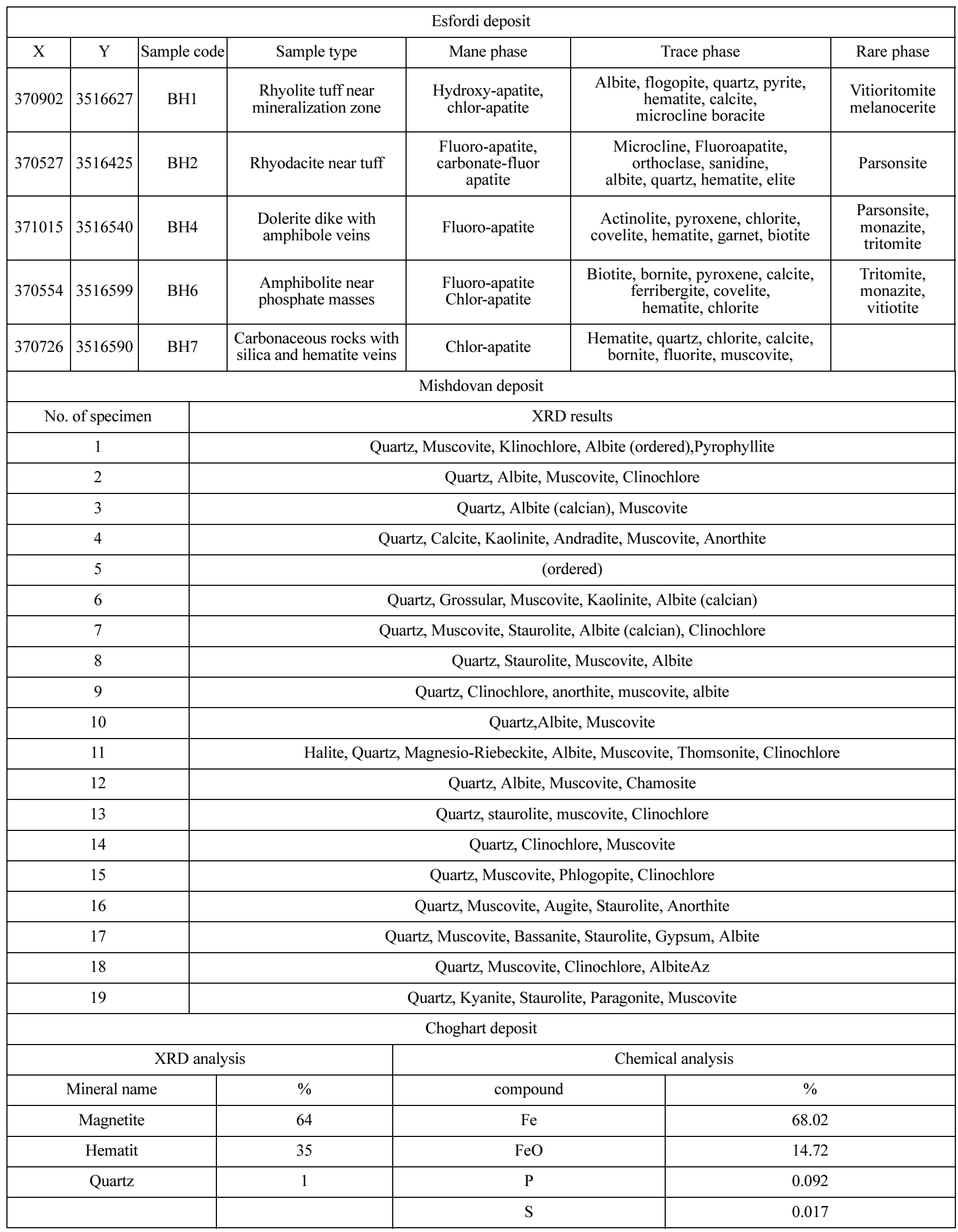


Table 3. (continued)

\begin{tabular}{|c|c|c|c|c|}
\hline \multicolumn{5}{|c|}{ Gazestan deposit } \\
\hline $\mathrm{X}$ & Y & Sample cod & Mineralization/Alltration/ unit & XRD results \\
\hline 400947 & 3502935 & SH5-1A & Magnetite-Apatite Mineraliztion & $\begin{array}{c}\text { magnetite, Hematite, calcite, Clino Chlor, goethite, Quartz, } \\
\text { Albite, fluoro Apatite, }\end{array}$ \\
\hline 401332 & 3502859 & SH5-3A & Magnetite-Apatite Mineraliztion & Magnetite, Hematite, Quartz, clino Chlor, \\
\hline 401415 & 3502790 & SH5-4A & metasomatismed Rhyolite & clino Chlor, Quartz, calcite, Orthoclase, Illite, Magnetite, Albite \\
\hline 401060 & 3502867 & SH5-2A & $\begin{array}{l}\text { Argillic alteration in metasomatismed } \\
\text { Rhyolite }\end{array}$ & Calcite, Quartz and Montmorillonite \\
\hline 401066 & 3503365 & SH5-5A & $\begin{array}{l}\text { Argillic alteration in metasomatismed } \\
\text { Rhyolite }\end{array}$ & Quartz, Calcite, Moscovite, Albite, clino Chlor, Orthoclase \\
\hline 400485 & 3502796 & SH5-6A & Volcanic dockite unit & Quartz, Hematite, Orthoclase, Moscovite, Iliiite, \\
\hline 400554 & 3502885 & SH5-7A & Metasomatismed Rhyolite & lino Chlor, Magnetite, Quartz, Albite, Hematite, Orthoclase \\
\hline 400691 & 3503073 & SH5-8A & High intensity metasomatismed part & Quartz, Calcite, Moscovite, Albite, clino Chlor, Orthoclase \\
\hline 400620 & 3502450 & SH5-9A & $\begin{array}{l}\text { Iron oxcide silisic alteration in } \\
\text { dockite-Rhyodockite unit }\end{array}$ & Quartz, Orthoclase, Magnetite, Jarosite, Albite and Moscovite \\
\hline 400548 & 3502499 & SH5-10A & Argillic alteration & Quartz, Orthoclase, Moscovite and dickite \\
\hline 401639 & 3502795 & SH5-11A & metasomatismed Rhyolite & $\begin{array}{l}\text { Clino Chlor, Magnetitet, Albite, Orthoclase, } \\
\text { Hematite and Moscovite }\end{array}$ \\
\hline 400680 & 3502845 & SH5-12A & metasomatismed Rhyolite & $\begin{array}{l}\text { Clino Chlor, Magnetite, Quartz, Albite, } \\
\text { Orthoclase and Moscovite }\end{array}$ \\
\hline 401464 & 3502706 & SH5-13A & metasomatismed Rhyolite & $\begin{array}{c}\text { Clino Chlor, Magnetite, Quartz, Albite, Orthoclase, } \\
\text { Hematite, Moscovite and Tremolite }\end{array}$ \\
\hline 401088 & 3502765 & SH5-14A & metasomatismed Rhyolite & $\begin{array}{c}\text { Clino Chlor, Magnetite, Orthoclase, Quartz, Albite, } \\
\text { Dickite, Biotite }\end{array}$ \\
\hline 400668 & 3502820 & SH5-15A & metasomatismed Rhyolite & $\begin{array}{l}\text { Clino Chlor, Quartz, Magnetite, Albite, Illite, } \\
\text { Orthoclase, Moscovite }\end{array}$ \\
\hline
\end{tabular}

\section{Acknowledgements}

The authors are grateful to Mr. Hassan Khairollahi, Saeid Goodarzi and Ms. Masoumeh Khalaj Masoimi from Geological Survey of Iran and Shahab Khoushabi for guiding some geology softwares.

\section{References}

Abrams, M., 2000, The Advanced Space borne Thermal Emission and Reflection Radiometer (ASTER): data products for the high spatial resolution imager on NASA TERRA Platform. International Journal of Remote Sensing, v. 21 pp. 847-859.

Adham, M.I., Jahan, C.S., Mazumder, Q.H., Hossain, M.M.A., and Haque, A.L., 2010, Study on groundwater recharge potentiality of Barind Tract, Rajshahi District, Bangladesh using GIS and remote sensing technique. Journal of the Geological Society of India, v. 75. https://doi.org/10.1007/s12594-010-0039-3

Adib, A., Afzal, P., Mirzaei Ilani, S., and Aliyari, F., 2017, Determination of the relationship between major fault and zinc mineralization using fractal modeling in the Behabad fault zone, central Iran. Journal of African Earth Sciences, v. 134, pp. 308-319.

Aghanabati, A., 2004, Geology of Iran. Geological Survey of Iran, Tehran, $600 \mathrm{p}$.

Aghanabati, A., 2008, Stratigraphy Encyclopedia of Iran: Precambrian to Silurian. Geological Survey of Iran, Tehran, 658 p.
Alavi, M., 1991, Tectonic map of the Middle East (scale 1:5,000,000). Geological Survey of Iran, Tehran.

Arian, M., 2011, Basement Tectonics and Geology of Iran. Asar Nafis Press, Qom, $300 \mathrm{p}$.

Arian, M., 2013, Physiographic-tectonic zoning of Iran's sedimentary basins. Open Journal of Geology, v. 3, pp.169-177.

Asadi Haroni, H., and Lavafan, A., 2007, Integrated analysis of ASTER and Landsat ETM data to map exploration targets in the Muteh goldmining area, Iran. Proceedings of the $5^{\text {th }}$ International Symposium on Spatial Data Quality, 2007, International Society for Photogrammetry and Remote Sensing, v. XXXVI-2/C43. http://www.isprs.org/proceedings/XXXVI/2-C43/Postersession/ASADI.pdf

Azizi, H., Tarverdi, M.A., and Akbarpour, A., 2010, Extraction of hydrothermal alterations from ASTER SWIR data from East Zanjan, Northern Iran. Advances in Space Research, v. 46, pp. 99-109. https://doi.org/ 10.1016/j.asr.2010.03.014

Barani, K., Javad Koleini, S.M., and Rezaei, B., 2011, Magnetic properties of an iron ore sample after microwave heating. Separation and Purification Technology, v. 76, pp. 331-336.

Berberian, M., 1981, Structural evolution of the Iranian Plateau: contribution to the seismotectonics of Iran (Part IV). Report No. 52, Geologic Survey of Iran, Tehran, pp. 19-66.

Berberian, M., and King, G.C.P., 1981, Towards a paleogeography and tectonic evolution of Iran. Canadian Journal of Earth Science, v. 18, pp. 210-265.

Burrough, P.A., and McDonnell, R.A., 1998, Principles of Geographical Information Systems. Oxford University Press, Oxford, $333 \mathrm{p.}$

Calder, C., and Cressie, N.A., 2009, Kriging and variogram models. In: Kitchin, R., and Thrift, N. (Eds.), International Encyclopaedia of Human 
Geography. Elsevier, Oxford, v. 1, pp. 49-55. https://doi.org/10.1016/ B978-008044910-4.00461-2

Daliran, F., Stosch, H.G., and Williams, P., 2009, A review of the Early Cambrian magmatic and metasomatic events and their bearing on the genesis of the Fe oxide-REE-apatite deposits (IOA) of the Bafq District, Iran: smart science for exploration and mining. Proceedings of the $10^{\text {th }}$ Biennial SGA Meeting, 2009, The Society for Geology Applied to Mineral Deposits, pp. 623-625.

Daliran, F., Stosch, H.G., Williams, P., Jamli, H., and Dorri, M.B., 2010, Early Cambrian iron oxide-apatite-REE (U) deposits of the Bafq District, east-central Iran. In: Corriveau, L., and Mumin, H., (Eds.), Exploring for Iron Oxide Copper-Gold Deposits: Canada and Global Analogues. Geological Association of Canada, Short Course Notes, v. 20, pp. 143-155.

Deutsch, C.V., and Journel, A.G., 1998, GSLIB: Geostatistical Software Library and User's Guide. Oxford University Press, New York, 369 p.

Dobrin, M.B., and Savit, C.H., 1988, Introduction to Geophysical Prospecting. McGraw-Hill, New York, 867 p.

Feumoe, A.N.S., Ndougsa-Mbarga, T., Manguelle-Dicoum, E., and Fairhead, J.D., 2012, Delineation of tectonic lineaments using aeromagnetic data for the south-east Cameroon area. Geofizika, v. 29, pp. 174-192.

Forster, H.G., and Jafarzadeh, A., 1994, The Bafq mining district in central Iran: a highly mineralized Infracambrian volcanic field. Economic Geology, v. 89, pp. 1697-1721.

Green, A.A., Berman, M., Switzer, P., and Craig, M.D., 1988, A transformation for ordering multispectral data in terms of image quality with implications for noise removal. IEEE Transactions on Geoscience and Remote Sensing, v. 26, pp. 65-74. https://doi.org/10.1109/36.3001

Haghipour, A., 1974, Etude geologique de la region de Biabanak-Bafq (Iran Central): petrologie et tectonique du socle Precambrien et de sa couverture (M.Sc. Thesis). Universite Scientifique et Medicale de Grenoble, Grenoble, France, 403 p.

Haghipour, A., 1977, Geological map of Posht-e-Badam area. Geological Survey of Iran, Tehran.

Haghipour, A., and Pelissier, G., 1977, Geology of the Saghand Sector. In: Haghipour, A., Valeh, N., Pelissier, G., and Davoudzadeh, M. (Eds.), Explanatory Text of the Ardekan Quadrangle Map. Geological Survey of Iran, Tehran, v. 8, pp. 10-68.

Huckriede, R., Kursten, M., and Venzlaff, H., 1962, Zur geologie des gebiets zwischen Kerman and Saghand (Iran). Beihefte zum Geologischen Jahrbuch, v. 51.

Imidro, C., 2015, Final report of the exploration operation performance in Gazestan mining area, topography and geology map. Iranian Mines and Mining Industries Development and Renovation Organization (IMIDRO), Parsi Kankav Consultant mining Engineers, 123 p.

Javed, A., and Wani, M.H., 2009, Delineation of groundwater potential zones in Kahund watershed, eastern Rajasthan, using remote sensing and GIS techniques. Journal of the Geological Society of India, v. 73, pp. 229-236. https://doi.org/10.1007/s12594-009-0079-8

Kruse, F.A., Boardman, J.W., Lefkoff, A.B., Heidebrecht, K.B., Shapiro, A.T., Barloon, P.J., and Goetz, A.F.H., 1993, The spectral image processing system (SIPS) - interactive visualization and analysis of imaging spectrometer data. Remote Sensing of Environment, v. 44, pp. 145-163.

Kujjo C.P., 2010, Application of remote sensing for gold exploration in the Nuba Montains, Sudan. M.Sc. Thesis, Bowling Green State University, Bowling Green, US, 99 p.

Malekzadeh, A., Karimpour, M.H., Stern, C.R., and Mazaheri, S.A., 2009, Hydrothermal alteration mapping in SW Birjand, Iran, using the advanced space borne thermal emission and reflection radiometer (ASTER) image processing. Journal of Applied Sciences, v. 9, pp. 829-842.

Mohamadi, F., Ebrahimi, M., and Mokhtari, M.A.A., 2016, Petrology and geochemistry of Homijan granitoid and associated felsic rocks (SW Behabad, Central Iran). Geosciences, v. 25, pp. 223-236.

Mohseni, S., and Aftabi, A., 2015, Structural, textural, geochemical and isotopic signatures of synglaciogenic Neoproterozoic banded iron formations (BIFs) at Bafq mining district (BMD), Central Iran: the possi- ble Ediacaran missing link of BIFs in Tethyan metallogeny. Journal of Ore Geology Reviews, v. 71, pp. 215-236.

Moore, F., and Modabberi, S., 2003, Origin of Choghart iron oxide deposit, Bafq mining district, Central Iran: new isotopic and geochemical evidence. Journal of Sciences, Islamic Republic of Iran, v. 14, pp. 259-270.

Nabilou, M., 2017, Structural modeling in Gazestan apatite_iron and rare elements deposit, Bafgh, Central Iran. Ph.D. Thesis, Islamic Azad University, Tehran, Iran, $223 \mathrm{p}$.

Nabilou, M., Arian, M., Afzal, p., Adib, A., and Kazemi Mehrnia, A., 2018, The relationship between Fe mineralization and the basement linear structures using multifractal modelling in the Bafq area, central Iran. Journal of Geociences, In press. (In Persian)

Namiranian, A., and Kalantar, M., 2014, Beneficiation and mullitization of Mishdovan and andalusite. Refractories and Industrial Ceramics, v. 55, pp. 295-303. https://doi.org/10.1007/s11148-014-9712-1

Pebesma, E.J., 2004, Multivariable geostatistics in S: the gstat package. Computer \& Geosciences, v. 30, pp. 683-691.

Pour, A.B., and Hashim, M., 2012, Identifying areas of high economicpotential copper mineralization using ASTER data in the UrumiehDokhtar Volcanic Belt, Iran. Advances in Space Research, v. 49. https:/ /doi.org/10.1016/j.asr.2011.11.028

Qorashi, M., and Arian M., 2011, Tectonics of Iran. Geological Survey of Iran, Tehran, $336 \mathrm{p}$.

Rajabi, A., 2008, Geology, mineralogy, texture and structure, geochemistry and genesis of Chahmir $\mathrm{Zn}-\mathrm{Pb}$ deposit, south of Behabad, Yazd Province. M.Sc. Thesis, Tarbiat Modares University, Tehran, Iran, 300 p.

Rajabi, A., 2012, Ore controlling parameters and genesis of SedimentaryExhalative $\mathrm{Zn}-\mathrm{Pb}$ (SEDEX type) deposits, Zarigan-Chahmir Area, East of Bafq, Central Iran. Ph.D. Thesis, Tarbiat Modares University, Tehran, Iran, $420 \mathrm{p}$.

Rajabi, A., Canet, C., Rastad, E., and Alfonsod, P., 2014, Basin evolution and stratigraphic correlation of sedimentary-exhalative $\mathrm{Zn}-\mathrm{Pb}$ deposits of the Early Cambrian Zarigan-Chahmir Basin, Central Iran. Journal of Ore Geology Reviews, v. 64, pp. 328-353.

Rajabi, A., Rastad, E., Alfonso, P., and Canet, C., 2012, Geology, ore facies and sulfur isotopes of the Koushk vent-proximal sedimentary-exhalative deposit, Posht-e-Badam block, Central Iran. Journal of International Ore Geology Reviews, v. 54, pp. 1635-1648

Rajabzadeh, M.A., Hoseini K., and Moosavinasab, Z., 2014, Mineralogical and geochemical studies on apatites and phosphate host rocks of Esfordi deposit, Yazd province, to determine the origin and geological setting of the apatite. Journal of Economic Geology, v. 6, pp. 331-353.

Rajendran, S., Al-Khirbash, S., Pracejus, B., Nasir, S., Al-Abri, A.H., Kusky, T.M., and Ghulam, A., 2012, ASTER detection of chromite bearing mineralized zones in Semail Ophiolite Massifs of the northern Oman Mountains: exploration strategy. Journal of Ore Geology Reviews, v. 44, 121-135.

Ramezani, J., and Tucker, R.D., 2003, The Saghand region, central Iran: $\mathrm{U}-\mathrm{Pb}$ geochronology, petrogenesis and implications for Gondwana tectonics. American Journal of Science, v. 303, pp. 622-665.

Rossi, M., and Deutsch, C., 2014, Mineral Resource Estimation. Springer, Dordrecht, $372 \mathrm{p}$.

Sadeghi, B., Khalajmasoumi, M., Afzal, P., Moarefvand, P., Yasrebi, A.B., Wetherelt, A., Foster, P., and Ziazarifi, A., 2013, Using ETM+ and ASTER sensors to identify iron occurrences in the Esfordi 1:100000 mapping sheet of Central Iran. Journal of African Earth Sciences, v. 85, pp. 103-114.

Sadeghi, B., Moarefvand, P., and Afzal, P., 2011, Determination of Fe grade distribution by using of concentration-number fractal method in boreholes of Zaghia iron ore deposit, Bafq. Earth Resource Journal, v. 3, pp. 51-60.

Salem, S.M., Arafa, S.A., Ramadan, T.M., and El Gammal, E.S.A., 2013, Exploration of copper deposits in Wadi El Regeita Area, southern Sinai, Egypt, with contribution of remote sensing and geophysical data. Arabian Journal Geoscience, v. 6, pp. 321-335. https://doi.org/10.1007/ 
S12517-011-0346-Z

Samani, B., 1993, Saghand formation, a riftogenic unit of upper Precambrian in central Iran. Journal of Geoscience, v. 6, pp. 32-45.

Shahbeik, S.h., Afzal, P., Moarefvand, P., and Qumarsy, M., 2014, Comparison between Ordinary Kriging $(\mathrm{OK})$ and Inverse Distance Weighted (IDW) based on estimation error case study: in Dardevey iron ore deposit, NE Iran. Arabian Journal of Geosciences, v. 7, pp. 3693-3704.

Stocklin, J., 1977, Structural correlation of the Alpine Ranges between Iran and Central Asia. Société Géologique de France, Paris, Mémoire Hors Série, v. 1, pp. 333-353.

Stosch, H.G., Romer, R.L., Daliran, F., and Rhede, D., 2011, UraniumLead ages of apatite from iron oxide ores of the Bafq District, EastCentral Iran. Mineralium Deposita, v. 46, pp. 9-21.

Verdel, C., Wernicke, B.P., Renne, P.R., and Spell, T.L., 2007, Geology and thermochronology of Tertiary Cordilleran-style metamorphic core complexes in the Saghand region of central Iran. Journal of Geological Society of America Bulletin, v. 119, pp. 961-977.

VerHoef, J.M., and Cressie, N., 1993, Multivariable spatial prediction. Math Geology, v. 252, pp. 219-239.

Wackernagel, H., 2003, Multivariate Geostatistics: An Introduction with Applications. Springer, Berlin, $387 \mathrm{p}$.

Watanabe, H., and Matsuo, K., 2003, Rock type classification by multiband TIR of ASTER. Geosciences Journal, v. 7, pp. 347-358. https:// doi.org/10.1007/BF02919567

Webster, R., and Oliver, M., 2001, Geostatistics for Environmental Scientists. John Wiley and Sons, Ltd., Chichester, 271 p.

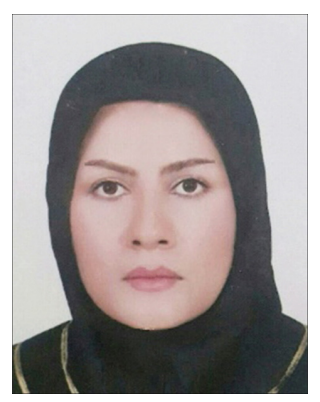

Masoumeh Nabilou has Ph.D. in structural geology from Islamic Azad University Science \& Research branch, Tehran, Iran. Her thesis title is "Structural modeling in Gazestan apatite iron and rare elements deposit, Bafq, Central Iran". She has got some paper about faulting, seismology, active tectonics, and relation between structural features and mineralization.

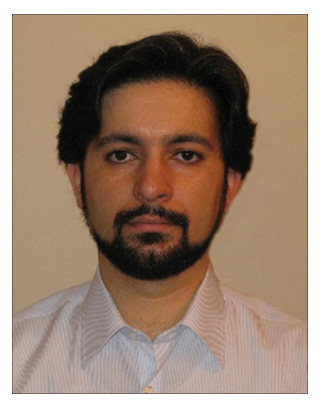

Mehran Arian, professor, was born in 1973, in Tehran, Iran. He graduated in Ph.D. on structural geology from Shahid Beheshti University, Iran. He is teaching at Science and Research branch, Islamic Azad University, Tehran, Iran since 2002. His interests are mineralization and tectonics.

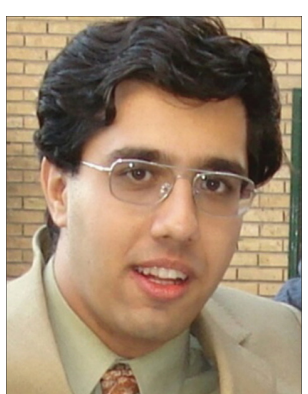

Peyman Afzal currently is an associate professor at the department of mining engineering, faculty of technology and engineering, Islamic Azad University-South Tehran Branch. He does research in economic geology, geochemistry, geostatistics and fractal modeling in earth sciences. He was a guest editor of "Journal of Geochemical Exploration" in 2017 and also, he is a member of editorial board for "Iranian Journal of Earth Sciences" and "Bulletin of the Mineral Research and Exploration".

Ahmad Adib has Ph.D. in structural geology and tectonics that dissertation is in "Structural Analysis and Active Tectonics of East Yazd, Central Iran", is an academic member of petroleum department of Azad University, south Tehran branch, and the head of "Geology and Environment Research Center" in Iran. Ahmad Adib has done many projects concerning faulting, seismology, active tectonics, and relation between structural features and mineralization.

Ahmad Kazemi Mehrnia is 43 years old, has more than 20 years of experience in copper and gold exploration, mineral mapping, managing mineral exploration projects, and has 10 years training in university of economic geology with some 20 lectures and papers. 